\title{
Analisa Kerusakan Superheater Tube Boiler Tipe ASTM A213 Grade T11 pada Pembangkit Listrik Tenaga Uap

\author{
Jeremy Adrian ${ }^{1}$, Nizhamul Latif ${ }^{2}$, Lukman Noerochim ${ }^{1}$, Budi Agung Kurniawan ${ }^{1}$ \\ ${ }^{1}$ Jurusan Teknik Material \& Metalurgi, Fakultas Teknologi Industri, Institut Teknologi Sepuluh \\ Nopember (ITS) \\ Jl. Arief Rahman Hakim, Surabaya 60111 Indonesia \\ ${ }^{2}$ Badan Pengkajian dan Penerapan Teknologi, Kawasan Puspiptek, Serpong, Tangerang Selatan \\ e-mail: lukman@mat-eng.its.ac.id
}

\begin{abstract}
Abstrak-Boiler memiliki peranan penting di dalam pembangkit listrik tenaga uap di indonesia. Pada pipa boiler sering terjadi kegagalan terutama pada pipa superheater. Superheater ini merupakan komponen dimana uap air dipanaskan sampai temperatur tinggi sehingga memiliki tekanan yang cukup untuk menggerakan generator pada PLTU. Superheater mengalami kerusakan berupa pecah ke luar (burst) dikarenakan penipisan pipa. Kegagalan ini terjadi setelah pemakaian selama 12,8 tahun. Dari hasil pengujian komposisi diketahui bahwa pipa superheater ini merupakan alloy Steel dengan tipe ASTM A213 grade T11. Hasil metalografi menunjukan struktur mikro pada material ini adalah ferit dengan ukuran butir pada daerah yang rusak lebih besar daripada daerah yang masih baik. Pada hasil metalografi juga ditunjukan dengan adanya void dan crack yang muncul pada batas butir. Pada pengujian hardness diketahui bahwa daerah masih baik memiliki kekerasan rata-rata 52 HRB dan pada daerah yang mengalami kerusakan memiliki hasil uji kekerasan rata-rata sebesar 25,5 HRB. Dari data SEM diketahui berkas patahan yang terjadi merupakan patah ulet dan terdapat intergranular crack pada permukaan. Adanya Thermal Fatigue menyebabkan adanya creep sebagai sumber terjadinya kegagalan material
\end{abstract}

Kata kunci - Superheater, shutdown, kerusakan , Alloy Steel, burst.

\section{PENDAHULUAN}

$\mathrm{P}$ EMBANGKIT listrik tenaga uap merupakan salah satu jenis pembangkit listrik yang paling sering digunakan di Indonesia. Pada pembangkit listrik tenaga uap atau PLTU, boiler memegang peranan penting sebagai penghasil uap. Pada pembangkit listrik tenaga uap, batu bara digunakan untuk menaikkan temperatur dari tabungtabung dengan temperatur 530-1000 ${ }^{\circ} \mathrm{C}$. Paparan temperatur tinggi pada luar tabung, tekanan tinggi yang ada di dalam, dan juga api yang telah terkontaminasi dengan residu yang bersifat korosif dalam jumlah waktu yang lama akan menyebabkan kegagalan pada pipa [1].

Coal-fired boiler atau boiler berbahan baku batu bara memegang peranan penting dalam industri pembangkit listrik di seluruh dunia, dengan menyuplai uap bertekanan tinggi untuk memutar generator [2]. Tabung superheater biasanya terletak pada zona terpanas dari boiler ataupun Steam Generator. Uap yang memiliki temperatur tinggi dan tekanan tinggi dimasukan kedalam tabung superheater yang akan terkena temperatur yang sangat tinggi dari pembakaran batu bara [3]. Karena itu, tabung superheater rentan akan kegagalan korosi dan patah pada temperature tinggi. Walaupun material dari superheater memliki sifat yang lebih baik daripada material lainnya pada boiler, tetapi kegagalan pada tabung superheater sering terjadi [4]. Untuk mencegah terjadinya kegagalan, yang berlanjut pada shut down suatu proses, harus dilakukan beberapa assessment untuk menghindari terjadinya proses shutdown.

Kegagalan pada pipa boiler ini dapat berdampak besar dalam proses ataupun didalam kerugian yang ditimbulkan. Ketika terjadi kegagalan harus dicari dengan benar apakah akar permasalahan yang tepat untuk menghilangkan ataupun mengurangi kegagalan yang dimungkinkan terjadi di masa depan. Maka dari itu dilakukan sebuah analisa yang dapat mengetahui penyebab dari kegagalan yang ditimbulkan. Beberapa jenis kegagalan yang dapat terjadi antara lain: caustic attack, hydrogen damage, oxygen pitting, acid attack, stress corrosion cracking, water corrosion fatigue, superheater fireside ash corrosion, fireside corrosion fatigue, short-term overheat, long-term overheat, dissimilar metal weld (DMV) failure, erosion, dan mechanical fatigue [5]. Untuk dapat mengetahui penyebab kegagalan serta mekanisme kegagalan dari pipa superheater maka dilakukan penelitian lebih lanjut agar dapat mencegah kegagalan serupa terjadi.

\section{II.METODE PENELITIAN}

\section{A. Studi Literatur dan Preparasi Spesimen}

Pertama dilakukan Studi literatur dan pengambilan sampel yang diteliti di PUSPITEK, Serpong, Tangerang, Banten. Setelah dilakukan pengambilan maka selanjutnya dilakukan persiapan spesimen sebelum dilakukan pengujian untuk menentukan kegagalan apa yang terjadi pada superheater tube boiler.

\section{B. Pengamatan Secara Makroskopis}

Pengamatan makroskopis ini dilakukan untuk mengetahui keadaan fisik dari spesimen yang didapatkan. Setelah dilakukan pengamatan selanjutnya di dokumentasikan menggunakan kamera digital.

\section{Pengujian Komposisi Kimia}

Komposisi kimia suatu bahan diidentifikasi dengan alat OES atau Spectrometer. Setelah dilakukan pengujian maka diketahui komposisi kimia dari ASTM A213 Grade T11 secara kuantitatif. Mekanisme dari uji komposisi menggunakan OES adalah memantulkan berkas elektron dari spesimen yang kemudian ditangkap oleh reseptor dan 
hasilnya langsung di tampilkan ke dalam komputer. Hasil dari uji ini menunjukan unsur yang terdapat di dalam spesimen dan kuantitasnya. Mesin uji komposisi kimia yang digunakan adalah PMI-MasterPro yang dilakukan di PUSPITEK Tangerang.

\section{Pengujian Metallography}

Pengamatan mikroskopik dengan menggunakan pengujian metallografi dilakukan untuk menganalisa suatu fasa, bentuk, dan ukuran dari struktur mikro yang terdapat pada material yang masih bagus dan material yang terjadi kerusakan.

Pengujian metalografi ditujukan untuk melihat struktur logam secara makro ataupun mikro yang terdapat pada komponen menggunakan mikroskop optik. Pengamatan dari struktur tersebut a memberikan informasi tentang tipe, ukuran butir distribusi, dan jumlahnya. Yang nantinya memberikan nilai property dari material tersebut. Metalografi ini megambil acuan dari ASM Handbook Volume 9 [6].

\section{E. Pengujian Hardness}

Pengujian ini dilakukan untuk mengetahui kekerasan material setelah melalui proses pada industri untuk selanjutnya dibandingkan dengan standar material yang terdapat pada ASTM. Pada pengujian hardness digunakan mesin uji hardness dengan metode Rockwell. Uji Rockwell dilakukan dengan penekanan sebuah bola baja yang terbuat dari baja yang telah dikeraskan dengan diameter tertentu, oleh gaya tekan secara statis kedalam permukaan logam yang diuji harus rata dan bersih [7]. Pengujian hardness yang dilakukan adalah pada permukaan diameter. Sampel yang dilakukan uji hardness sebanyak 3 buah yaitu pada bagian yang masih bagus, di tepi terjadinya kerusakan dan pada bagian yang terjadi kerusakan. Alat uji kekerasan yang dipakai merupakan model HBRV-187 5 yang terdapat di Laboratorium Metalurgi Teknik Material dan Metalurgi ITS.

\section{F. Pengujian SEM}

Scanning Electron microscope (SEM) merupakan salah satu alat pengujian material yang biasanya digunakan untuk mengetahui profil permukaan dan patahan. Hasil dari mesin SEM berupa gambar 3-dimensi yang menunjukan permukaan dari spesimen. Spesimen yang akan dilakukan uji sem diambil dari tepi bagian yang mengalami kerusakan. Mesin SEM yang digunakan merupakan mesin SEM dengan tipe SEM Inspect S50.

Adapun cara kerja dari SEM adalah electron gun memproduksi electron beam, anoda menangkap electron beam untuk kemudian diarahkan ke sampel kemudian serangkaian lensa magnetik memfokuskan beam ini dan menembakkan ke sampel, scanner membaca struktur permukaan sampel selanjutnya menangkap sinyal dari secondary dan back scattered electron untuk dikirim ke sistem kontrol sehingga dapat dilihat gambarnya pada monitor dan dapat dicetak bila diperlukan.

\section{III.ANALISA DATA DAN PEMBAHASAN}

\section{A. Hasil Pengujian Komposisi Kimia}

Tabel 1 menunjukkan data pengujian komposisi material yang mengalami kerusakan.
Tabel 1

Hasil Uji Spektrometer

\begin{tabular}{ccc}
\hline \hline Unsur & Hasil Uji & ASTM A213 \\
\hline $\mathrm{C}$ & 0,126 & $0,05-0,15$ \\
$\mathrm{Si}$ & 0,17 & $0,25-1,00$ \\
$\mathrm{Mn}$ & 0,541 & $0,3-0,6$ \\
$\mathrm{P}$ & 0,0309 & $0,025 \mathrm{max}$ \\
$\mathrm{S}$ & 0,0081 & $0,025 \mathrm{max}$ \\
$\mathrm{Cr}$ & 1,09 & $1,0-1,5$ \\
$\mathrm{Mo}$ & 0,308 & $0,44-0,65$ \\
$\mathrm{Fe}$ & Balance & Balance \\
\hline \hline
\end{tabular}

Dari hasil uji spektometer, dapat dilihat bahwa hasil uji spesimen dari benda yang mengalami kegagalan mendekati standar ASTM A213 Grade T11[8]. Meskipun kandungan fosfor dan molybden tidak masuk batas komposisi, tetapi material ini tetap merupakan ASTM A213 Grade T11 karena fosfor dan molybden bukan penyusun utama dari ASTM A213 Grade T11. Bagian yang diperiksa merupakan bagian luar dari tube, yang mengalami paparan panas batu bara secara langsung. ASTM A213 Grade T11 ini termasuk ke dalam golongan baja karbon rendah. Baja karbon rendah sendiri memiliki keuletan yang tinggi, kekerasan yang rendah, mudah di las tetapi memiliki sifat machinability yang rendah.

\section{B. Hasil Pengujian Metalografi}

Hasil Metalografi dibagi menjadi 3 bagian yang merajuk pada lokasi terjadinya kerusakan yang akan ditunjukan dalam Gambar 1.

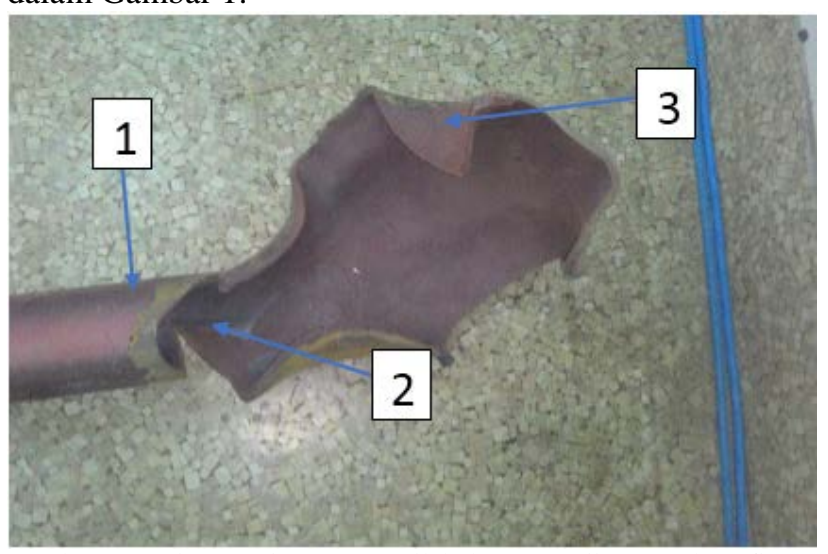

Gambar 1. Bagian Spesimen yang Dilakukan Pengujian Metalografi

Bagian 1 merupakan bagian yang masih bagus dari pipa yang mengalami kerusakan. Bagian 1 ini diambil pada 30cm dari tepi kerusakan. Sedangkan bagian 2 merupakan bagian di tepi yang mengalami kerusakan. Dan bagian 3 merupakan tempat terjadinya kerusakan dengan distribusi temperatur yang digambarkan pada Gambar 2.

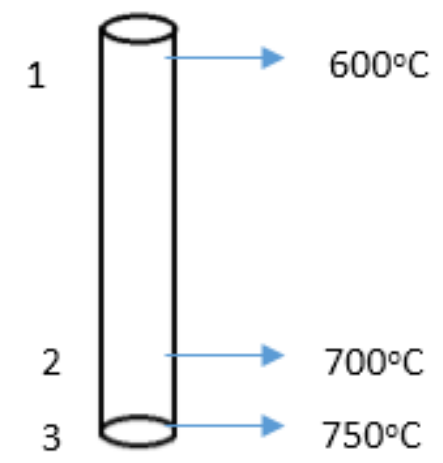

Gambar 2. Distribusi Temperatur 


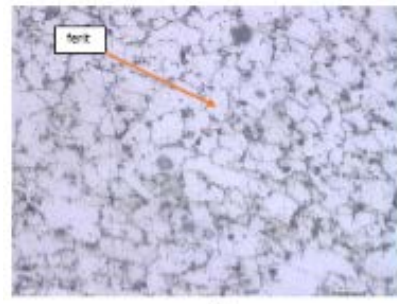

(a)

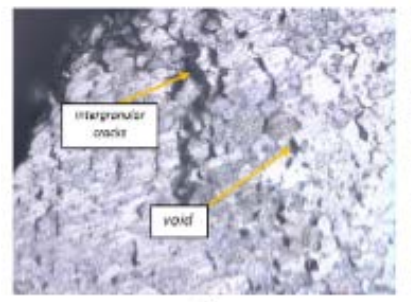

(c)

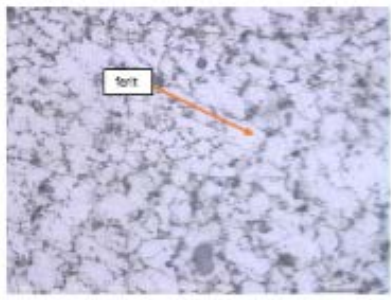

(b)

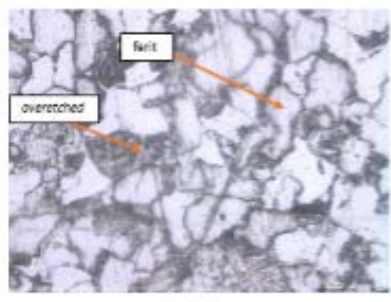

(d)

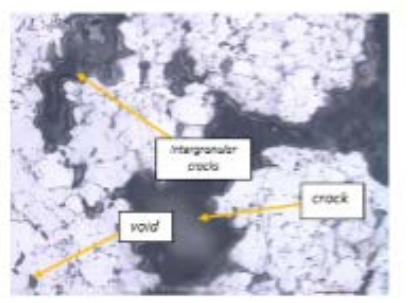

(e)

Gambar 3. Hasil Uji Metalografi (a) Bagian 1 pada perbesaran 500x; (b) Bagian 2 pada perbesaran 500x; (c) Bagian 2 pada perbesaran 500x; (d) Bagian 3 pada perbesaran 500x; (e) Bagian 3 pada perbesaran 500x.

ASTM A213 memiliki fasa ferit-perlit, dan dari struktur mikro diatas dapat dilihat bahwa fasa yang tampak berupa ferit. Fasa ferit ditampilkan dengan gambar terang, sedangkan fasa perlit terlihat dengan warna yang lebih gelap dan lamelar (struktur gelap-terang berlapis). Tetapi karena jumlah karbon yang sangat kecil, fasa perlit tidak tampak dalam Gambar 3(a), Gambar 3(b) dan Gambar 3(d). Warna gelap pada Gambar 3(d) merupakan bagian yang terkena etsa berlebih. Dari Gambar 3(c) dan Gambar 3(e) dapat terlihat bahwa pada material ini muncul void dan intergranular cracks seperti yang ditunjukan pada gambar.

\section{Hasil Pengujian Batas Butir}

Setelah melakukan pengujian Metalografi dan mendapatkan hasil struktur mikro, kemudian ditambahkan penghitungan untuk ukuran batas batas butir pada bagian 1,2 dan 3 dengan menggunakan standar ASTM E112[9]. Metode yang digunakan adalah metode Plainmetric, dengan mengacu pada Jeffrie's Procedure. Dari hasil perhitungan yang telah dilakukan, diintepretasikan ke dalam Tabel 2.

Tabel 2

Data Hasil perhitungan ukuran diameter butir

\begin{tabular}{ccc}
\hline \hline No. & Bagian Spesimen & $\begin{array}{c}\text { Rata-rata diameter } \\
(\mathrm{mm})\end{array}$ \\
\hline 1. & Bagian 1 & 0,0213 \\
2. & Bagian 2 & 0,0236 \\
3. & Bagian 3 & 0,0308 \\
\hline \hline
\end{tabular}

Dari hasil perhitungan diameter butir didapatkan bahwa diameter bagian 1 dan 2 hampir sama, sedangkan terjadi kenaikan pada bagian 3 .

\section{Hasil Pengujian Kekerasan}

Pengujian kekerasan bertujuan untuk mengetahui distribusi dari kekerasan pada masing masing daerah pipa yang rusak. Pengujian ini dilakukan dengan standar kekerasan Rockwell dengan mengacu pada ASTM E10 [7]. Hasil pengujian kekerasan ditampilkan pada Tabel 3.

Tabel 3

Rata-rata hasil uji kekerasan

\begin{tabular}{ccccc}
\hline \hline Material & ASTM & Bagian & Bagian & Bagian \\
& A213 & 1 & 2 & 3 \\
& T11 & & & \\
\hline Hardness & 85 HRB & 52 & 49 & 25,5 \\
Rockwell & & HRB & HRB & HRB \\
$\begin{array}{c}\text { Number rata- } \\
\text { rata }\end{array}$ & & & \\
\hline \hline
\end{tabular}

Dari hasil pengujian kekerasan yang telah dilakukan dapat dilihat bahwa bagian 1 memiliki kekerasan yang paling tinggi diikuti bagian 2 lalu bagian 3. Terlihat tren penurunan kekerasan dari bagian 1 ke bagian 3 .

\section{E. Hasil Pengujian SEM}

Pengujian SEM (Scanning Electron Microscope) hanya dilakukan pada bagian yang rusak (bagian 3). Pengujian Scanning electron microscope digunakan untuk mencari kondisi permukaan serta morfologi permukaan pada benda. Pengujian SEM dilakukan dalam 2 titik yang merupakan bagian dalam dan bagian luar. Pengujian SEM dilakukan dengan perbesaran 100X. Bagian yang dilakukan hasil uji SEM dapat dilihat pada Gambar 4(a). Hasil uji SEM bagian dalam ditampilkan pada Gambar 4(b) dan bagian luar pada Gambar 4(c).
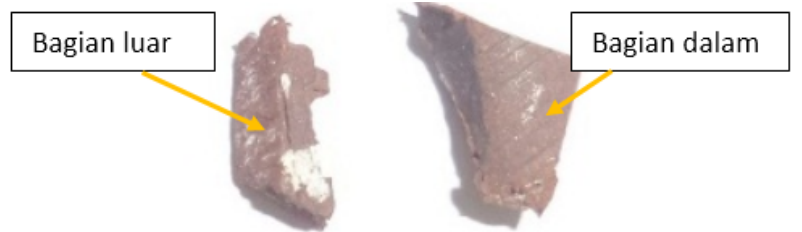

(a)

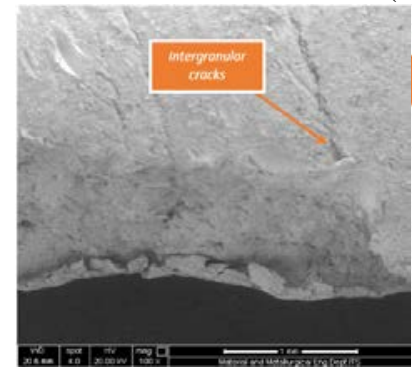

(b)

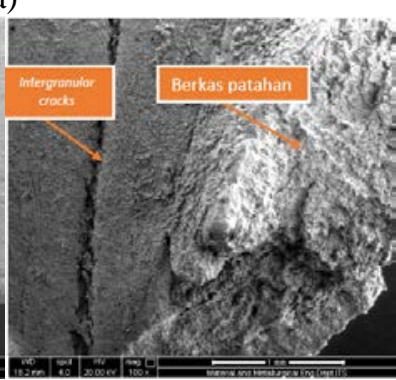

(c)
Gambar 4. Uji SEM (a) Spesimen uji SEM; (b) Hasil pengujian SEM bagian luar dengan perbesaran 100x; (c) Hasil pengujian SEM bagian dalam dengan perbesaran $100 \mathrm{x}$

Pada hasil pengujian SEM dengan perbesaran 100x dilakukan pada daerah dalam dan daerah luar pada bagian 3 (bagian yang mengalami kegagalan). Dapat dilihat beberapa profil permukaan yaitu dengan adanya intergranular crack yang tersebar di permukaan bagian dalam maupun bagian luar dari material yang mengalami kerusakan. Intergranular crack yang terjadi merupakan intergranular crack yang hanya terdapat pada permukaan dan tidak menembus ke permukaan sebaliknya. 
Intergranular crack pada bagian dalam terlihat lebih sedikit dibanding bagian luar. Dari Gambar 4(c) dapat dilihat bahwa berkas patahan yang terjadi berbentuk granular dan tidak mengkilap. Hal ini mengatakan bahwa patahan yang terjadi pada benda tersebut merupakan patahan yang terjadi secara cepat (rapid failure). Rapid failure ini terjadi karena penjuluran crack dari awal terjadinya crack sampai terjadi kerusakan berjalan dengan cepat.

\section{F. Pembahasan}

Pada Tabel 1 hasil uji spesimen dari benda yang mengalami kegagalan mendekati standar ASTM A213 Grade T11. ASTM A213 Grade T11 ini termasuk ke dalam golongan baja karbon rendah. Baja karbon rendah sendiri memiliki keuletan yang tinggi, kekerasan yang rendah, mudah di las tetapi memiliki sifat machinability yang rendah. Setelah mengetahui hasil spektrometer yang menunjukan bahwa material tersebut adalah ASTM A213 Grade T11 [8] selanjutnya dilakukan pengujian metalografi untuk mengetahui struktur mikro yang terdapat pada material yang mengalami kerusakan. Pengujian metalografi yang dilakukan dibagi ke dalam 3 bagian seperti yang ditampilkan pada Gambar 1. ASTM A213 memiliki fasa ferit-perlit, dan dari struktur mikro pada bagian 1 yang ditunjukan pada Gambar 3(a) dapat dilihat bahwa fasa yang tampak berupa ferit. Fasa ferit ditampilkan dengan gambar terang, sedangkan fasa perlit terlihat dengan warna yang lebih gelap dan lamelar (struktur gelap-terang berlapis). Tetapi karena jumlah karbon yang sangat kecil, fasa perlit tidak tampak dalam gambar. Pada struktur mikro bagian 1 dan 2 terlihat bahwa struktur mikro memiliki grain yang lebih kecil dibandingkan ketika kita merajuk pada gambar struktur mikro bagian 3 yang ditunjukan pada Gambar 3. Pada bagian 3 dapat disimpulkan bahwa terjadi deformasi dan perbesaran yang cukup besar pada ukuran butir, sedangkan fasa penyusun yang terlihat tetap yaitu ferit.

Setelah itu dilakukanlah perhitungan batas butir sesuai dengan ASTM E112 dan dapat dilihat dalam Tabel 2 bahwa diameter rata-rata butir pada bagian 1 yang paling kecil dan bagian 3 merupakan yang paling besar dengan bagian 2 di antaranya. Perbesaran butir terjadi karena adanya pemanasan yang terus menerus dalam waktu yang lama [10]. Keadaan material saat pemanasan boiler awal juga langsung dengan kenaikan panas yang tinggi sehingga bagian 3 yang merupakan bagian yang bawah dikenakan panas yang melebihi temperatur ketahanan panas dari ASTM A213 Grade T11 itu sendiri. Paparan panas yang terus menerus dalam temperatur tersebut akan menyebabkan perubahan struktur, yakni terjadinya perbesaran butiran pada material tersebut. Transformasi yang terjadi hanyalah transformasi struktur saja dan bukan transformasi fasa dari material tersebut. Bagian 3 memiliki butiran yang lebih besar dibandingkan butir pada bagian 1 dan bagian 2 karena bagian 3 lebih dekat dengan sumber panas batubara, sehingga temperatur yang mengenai bagian 3 lebih tinggi. Paparan panas yang terjadi adalah sekitar $540^{\circ} \mathrm{C}$ dalam kondisi ideal dan dalam kenyataannya temperatur yang digunakan melebihi dari temperatur ketahanan panas dari material yaitu sekitar $570^{\circ} \mathrm{C}$ (temperatur yang digunakan sekitar $750^{\circ} \mathrm{C}$ ).

Pada metalografi bagian 2 yang ditunjukan pada Gambar 3(c) dapat terlihat adanya intergranular crack dan void. Void merupakan sebuah rongga kosong yang terdapat pada batas butir sedangkan intergranular crack adalah void yang bergabung menjadi suatu muluran memanjang pada batas butir. Intergranular crack yang terlihat masih merupakan intergranular crack yang pendek dan belum menjuluh jauh. Kedalaman intergranular crack ini masih cenderung dangkal dan belum masuk jauh dan merusak struktur yang lainnya. Sedangkan pada bagian 3 yang ditunjukan pada Gambar 3(e) dilihat bahwa struktur mikro yang ada di bagian 3 ini memiliki intergranular crack, void, dan crack. Intergranular crack dan void yang ada pada bagian 3 ini mirip dengan yang ada di bagian 2 . Perbedaannya adalah dengan munculnya crack (retak), retak ini merupakan akibat dari intergranular crack yang menjalar secara cepat.

Dari hasil pengujian kekerasan yang ditampilkan pada Tabel 3 dapat dilihat bahwa nilai kekerasan pada spesimen menurun, penurunan yang terjadi cukup signifikan. Hal ini selaras dengan teori Hall-Petch dimana dikatakan bahwa semakin besar butir, maka kekerasan, kekuatan, serta ketangguhan material akan menurun dan berlaku sebaliknya [11]. Penurunan kekerasan tidak semata-mata hanya terjadi karena adanya perbesaran butir, tetapi dengan adanya pengeroposan pada material yang dapat dilihat dari hasil metalografi pada Gambar 3(c) dan Gambar 3(e) yang menunjukan material tersebut sudah memiliki void dan crack. Keberadaan void dan crack ini membuat material tersebut menjadi rapuh, sehingga kekuatannya menurun dengan signifikan.

Berdasarkan hasil pengujian SEM yang ditunjukan dengan Gambar 4(a) dan Gambar 4(b), dapat dilihat bahwa terdapat intergranular crack. Intergranular crack yang terdapat pada bagian 3 ini terdapat di bagian luar maupun dalam, tetapi lebih banyak terdapat pada bagian luar.

Intergranular crack ini ditimbulkan karena adanya aliran panas yang fluktuatif menyebabkan benda tersebut mengalami Thermal Fatigue. Temperatur pengoperasian yang dilakukan biasanya berlebih sehingga benda melewati temperatur ketahanan panasnya (diatas $570^{\circ} \mathrm{C}$ ) sehingga membuat benda ini mudah terdeformasi, dan karena deformasi yang terus menerus menyebabkan benda tersebut fatigue [12]. Thermal Fatigue ini membuat benda mulur ketika terkena panas dan menyusut ketika panas tersebut berkurang ataupun hilang. Fenomena ini disebut pemuluran atau creep yang nantinya menimbulkan void . Void muncul pada batas butir dan sejalan waktu void akan semakin banyak dan bertemu dengan void yang lain. Kumpulan void ini akan menjalar di batas butir dan membentuk Intergranular Crack [13]. Intergranular crack yang terjadi di banyak tempat menyebabkan material itu menjadi rentan, intergranular crack ini dapat bergabung dengan intergranular crack yang lain membentuk suatu crack. Jika crack ini terbentuk, besar kemungkinan suatu material mengalami kegagalan.

\section{KESIMPULAN}

1) Hasil analisa metalografi pada daerah yang tidak mengalami kegagalan, fasa yang tampak merupakan ferit dengan diameter rata2 butir sebesar 0,0213 mm dan memiliki kekerasan sebesar 52 HRB, pada tepi pipa yang pecah fasa yang tampak pada metalografi juga merupakan ferit dengan rata-rata diameter butir sebesar 0,02357 $\mathrm{mm}$ dan memiliki kekerasan sebesar 
49 HRB. Pada daerah yang mengalami kerusakan didapatkan bahwa fasa yang tampak merupakan ferit dengan rata-rata diameter sebesar 0,0308 mm dengan kekerasan sebesar 25,5 HRB.Pada hasil SEM terlihat adanya crack dan berkas patahan berupa granular.

2) Penyebab terjadinya kegagalan pada pipa superheater dikarenakan adanya creep yang menjulur dan mengakibatkan crack sebagai awal pecahnya pipa.

3) Mekanisme terjadinya creep berawal dari adanya kelelahan pada temperatur tinggi, yang mengakibatkan terbentuknya creep void pada batas butir. Void akan saling bertemu dan bergabung membentuk intergranular crack. Intergranular crack yang bergabung akan membentuk crack yang makin lama makin besar. Karena banyaknya crack maka material ini menjadi rentan dan terjadi burst (pecah).

\section{DAFTAR PUSTAKA}

[1] _ $ـ$ Our Boilers and Enviromental Equipment, Ohio: Babcox and Wilcox Company, 1998.

[2] P. Elie Tawil, Boiler Clasification and Application, New York: CEDengineering.com, 2009.

[3] _ _ Guideline for Gas and Oil Emission Factors for Industrial, Commercial, and Institutional (ICI) Boilers, Virginia, 1997.

[4] A. J. Sebastian Teir, Heat Exchangers in Boilers, Helsinki: Helsinki University of Technology, 2002.

[5] Z. Ahmad, Principles of Corrosion Engineering and Corrosion Control, London: Butterworth-Heinemann, 2006.

[6] — "ASM Handbook vol.9 Metallographic and Microstructure," ASM International, Ohio, 2002.

[7] — "ASTM E10 Standard Test Method For Hardness Of Metallic Materials," ASTM International, West Conshohocken, 2002.

[8] _ _ "A213 Standard Spesification for Seamless Ferritic and Austenitic Alloy-Steel Boiler, Superheater, adn Heat-Exchanger Tube," ASTM International, New York, 2006.

[9] _ _ "E112 Standard Test Methods for determining Average Grain Size," ASTM International, West Conshohocken, 2003.

[10] K. Chandra, V. Kain dan G. Dey, "Failure of 2.25Cr-1Mo Steel Superheater Tubes in A Fluidized Bed,” 2010.

[11] R. Amstrong, Engineering Science Aspects of The Hall-Petch Relation, Maryland, 2014.

[12] P. Psylaki, G. Pantazopoulos and H.Lefakis, "Metallurgical Evaluation of Creep-Failed Superheater Tubes," 2008.

[13] R. Higgins, Engineering Metalurgy Part 1, London: Arnold, 1999. 